\section{SPORT SCIENCES' SCIENTIFIC PRODUCTION PUBLISHED IN CHILE (1912-2014): A BIBLIOMETRIC APPROACH}

\author{
PRODUÇÃO CIENTÍFICA NA ÁREA DE CIÊNCIA DO ESPORTE NO CHILE \\ (1912-2014): UMA ABORDAGEM BIBLIOMÉTRICA
}

PRODUCCIÓN CIENTÍFICA EN EL ÁREA DE CIENCIAS DEL DEPORTE EN CHILE (1912-2014): UN ABORDAJE BIBLIOMÉTRICO

\author{
Mikel Pérez-Gutiérrez*, Roberto Iván Lagos-Hernández**, \\ Eugenio Izquierdo-Macón ${ }^{\star \star \star}$
}

\title{
Keywords
}

Sports.

Scientific and technological activities. Bibliometrics. Chile.

Palavras-chave Esportes. Atividades científicas e tecnológicas. Bibliometria. Chile.

Palabras clave Deportes. Actividades científicas y tecnológicas. Bibliometría. Chile.

\begin{abstract}
This study conducted a bibliometric analysis of Sport Sciences' scientific production published in Chile until 2014 in order to present its productivity and collaboration patterns. Articles and reviews' bibliographic information, authors' affiliation and country, decade, subject and research area were recorded and analysed. In summary, Sport Sciences production has progressively increased from the 1910 s onwards, depending on the socio-historical events that happened in Chile. During the 21 st century, a process of consolidation has started as a result of the amount of authors, journals, countries, research areas and subjects studied, therefore strengthening collaboration.
\end{abstract}

Resumo: 0 objetivo deste estudo foi desenvolver uma análise bibliométrica da produção científica em Ciências do Desporto publicada no Chile até 2014 para apresentar a sua produtividade e colaboração. $O$ estudo registra e analisa a informação bibliográfica, afiliação institucional, país, década, disciplina e área de artigos e resenhas. Em suma, a produção de Ciências do Esporte tem aumentado constantemente desde a década de 1910 em diante, dependendo dos acontecimentos sócio-históricos no Chile. Durante o século $\mathrm{XXI}$, começou um processo de consolidação em resposta ao número de autores, revistas, países, áreas de pesquisa e disciplinas estudadas, e a colaboração tem sido reforçada.

Resumen: El objetivo de este estudio fue desarrollar un análisis bibliométrico de la producción científica en Ciencias del Deporte publicada en Chile hasta 2014, para presentar su productividad y colaboración. El estudio registra y analiza la información bibliográfica, la afiliación institucional, país, década, disciplina y área de artículos y reseñas. En resumen, la producción de Ciencias del Deporte ha aumentado constantemente desde la década de 1910 en adelante, dependiendo de los acontecimientos socio-históricos en Chile. En el siglo XXI, ha comenzado un proceso de consolidación atendiendo a la cantidad de autores, revistas, países, áreas de investigación y disciplinas estudiadas y la colaboración se ha reforzado.
* Universidad Europea Miguel de Cervantes.Valladolid, Spain. Universidad de León.León, Spain.

E-mail: mperezg@uemc.es

** Universidad Autónoma de Chile. Temuco, Chile.

E-mail: roberto.lagos@uautonoma.cl

*** Universidad de León. León, Spain. E-mail: eugenio.izquierdo.macon@unileon.es

Recebido em: 13-05-2016 Aprovado em: 07-07-2016 (c) (1) () Licence 


\section{INTRODUCTION}

The growing social and political interest about physical activities from the $19^{\text {th }}$ century in Chile (CORNEJO AMÉSTICA; MATUS CASTILLO; VARGAS CONTRERAS, 2011, GUARDA ETCHEVERRY, 2006, MARTÍNEZ-FERNÁNDEZ, 2012, RUIZ URBINA, 1956) was finally materialized with the establishment of the Physical Education and Manual Institute at the University of Chile in 1906, being Sport Sciences recognized within higher education (COFRÉ ILUFFI, 1986, COFRÉ ILUFFI, 1989, GUARDA ETCHEVERRY, 2006, PÉREZ-GUTIÉRREZ; GUTIÉRREZ-GARCÍA, 2015). Thus, the Institute became a cornerstone for the preparation of physical education teachers, who were progressively included into schools along the country as well as the academic staff of the following universities and faculties that were created (COFRÉ ILUFFI, 1989), and the beginning of research in this topic.

From 1906 onwards, Sport Sciences have been progressively developed in Chile, depending on the social, political, economic and cultural events happened until present day. The economic effects of the Great Depression (COLLIER; SATER, 1996) during the 1930s, the university reforms carried out from 1960 to 1973 (CASALI FUENTES, 2011, GARRETÓN; MARTÍNEZ, 1985, HUNEEUS, 1988), the coup d'état and the establishment of Pinochet's military regime from 1973 to 1990 (SILVA GALDAMES, 1995) or the enactment of the 19712 Law of Sport in 2001 (MINISTERIO DEL INTERIOR, 2001) are some of these events influencing Sport Sciences' evolution. To date, several historical works have been carried out regarding Sport Sciences in Chile such as the description of the history of Physical Education (CORNEJO AMÉSTICA; MATUS CASTILLO; VARGAS CONTRERAS, 2011, MARTíNEZ-FERNÁNDEZ, 2012, POBLETE GÁLVEZ; MORENO DOÑA; RIVERA GARCÍA, 2014), the policies developed by the General Office of Sports and Recreation (MUÑOZ FUNCK, 2001), the Chilean sports history (MARÍN, 2007, MODIANO, 1997), the results of Chilean athletes (ABARZÚA ALARCÓN, 2005, MUÑOZ FUNCK, 2008, SOLÍS VALENZUELA, 2003) or the curriculum and policy of Physical Education (MORENO-DOÑA; GAMBOA JIMÉNEZ, 2014, MORENO DOÑA; GAMBOA JIMÉNEZ; POBLETE GÁLVEZ, 2014).

On the other hand, the enormous and complex rise of scientific research has turned bibliometrics the main tool for analyzing science (THOMSON REUTERS, 2008). In Chile, bibliometrics has been applied for studying country's research output (MOYA-ANEGÓN, 2014), scientific production of its universities (RAU, 2008) as well as for analyzing the features of several fields of knowledge such as agriculture (KRAUSKOPF, 2008), dentistry (CARTESVELÁSQUEZ; ARAVENA TORRES, 2012), ecology (JAKSIC; SANTELICES, 1991), medicine (KRAUSKOPF; KRAUSKOPF, 2008), psychology (FLORENZANO et al., 2011), radiology (GÁLVEZ et al., 2015) and surgery (ARAVENA; CARTES-VELASQUEZ; MANTEROLA, 2013, MORAGA et al., 2012). Specifically, bibliometrics has been recently used at the international level within Sport Sciences for studying journals (FERREIRA BARROS CARNEIRO et al., 2016, PERRINO PEÑA, 2014), books (PÉREZ-GUTIÉRREZ; GUTIÉRREZ-GARCÍA, 2008) trends and topics represented in the Social Science Citation Index (GAU, 2013) or the South-American research output (ANDRADE et al., 2013), to name a few. But few bibliometric studies have 
been carried out in Chile relating Sport Sciences, such as the analyses of the journals titled Educación Física-Chile (PÉREZ-GUTIÉRREZ; GUTIÉRREZ-GARCÍA, 2015) and Revista de Ciencias de la Actividad Física del Instituto Nacional de Deportes (PÉREZ-GUTIÉRREZ; LAGOS-HERNÁNDEZ, 2015). Bibliometric characteristics of Sport Sciences scientific journals (PÉREZ-GUTIÉRREZ; LAGOS-HERNÁNDEZ, 2015) or the distribution of Physical Education degree's dissertations among the campuses of the Universidad Autónoma de Chile (LAGOSHERNÁNDEZ; PÉREZ-GUTIÉRREZ, 2016) have been also analyzed. Due to the progressive growth of Sport Sciences from 1906 onwards and the lack of works analyzing its scientific output, the aim of the present study was to develop a bibliometric analysis of the Sport Sciences' scientific journals edited in Chile until 2014 for presenting its productivity and collaboration patterns.

\section{METHODOLOGY}

All articles and reviews published within Sport Sciences' scientific journals edited in Chile until 2014 were included in the present study. Other document types such as letters, reports, notes or editorials were not included since they are not derived from research.

\subsection{Information retrieval}

Scielo and Latindex databases as well as the online catalogues of Chilean National Library and university libraries were checked for discovering Sport Sciences scientific journals edited in Chile. Then, all journals' issues were consulted, most of them in the Chilean National Library, and/or downloaded from their webpages if possible. Articles and reviews' bibliographic information was registered in Endnote $\mathrm{X} 6$ reference manager programme following the recommendations of the Spanish Association for Standardization and Certification (AENOR, 2013), including author, year, title, journal's title, volume, issue and pages. Authors' address (affiliation and country) and decade of publication were recorded. Moreover, documents were classified according to their subject and research area, following the criteria used by Devís Devís et al. (2010) and the classification used in the Web of Science (THOMSON REUTERS, 2012) respectively.

\subsection{Data analysis}

Later, data was exported to Excel 2013 for carrying out the bibliometric analysis focused on productivity and collaboration aspects (LÓPEZ LÓPEZ, 1996). Regarding productivity, descriptive statistics were used for data analysis in relation to the distribution of articles, authors, institutions and countries per decade as well as the distribution of articles per decade, subject, research area and journal. Regarding collaboration patterns, single-authored articles (SA), multi-authored articles (MA), total articles (TA), mean of authors per article and percentage of collaboration $(\% \mathrm{C})$ were calculated and distributed per decade. Percentage of 
collaboration was calculated using the formula given by Valenciano Valcárcel et al. (2010), being: $\% C=M A / T A$.

\section{RESULTS}

A total of 3,436 articles published from 1912 to 2014 in 12 different journals were discovered (see Figure 1), presenting an irregular evolution along time. This production ranged from 144 articles published in 1930 to only six articles in 1913. Moreover, the scientific output disappeared in three different periods, such as 1916-1928, 1932-1933 and 1973.

Figure 1 - Distribution of articles per year

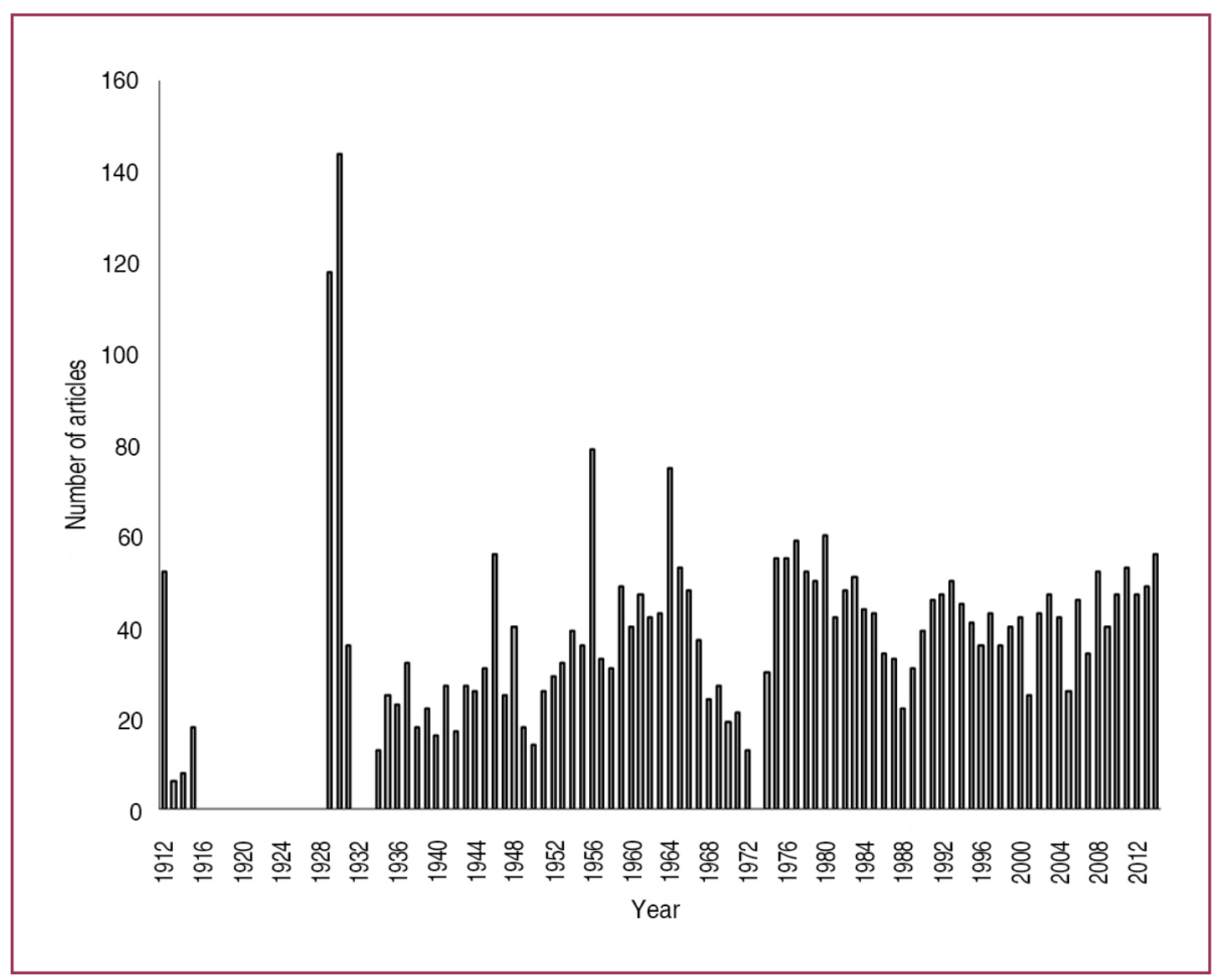

Source: prepared by authors

As Table 1 shows, Sport Sciences output has been carried out by 2,436 authors affiliated to 602 institutions from 47 different countries. Despite only five years have been considered for the last analyzed decade, the amount of articles, authors and institutions has progressively increased along time in contrast with the amount of countries. The 1960s was the most productive decade according to the amount of articles and countries while the first decade of the $21^{\text {st }}$ century achieved the highest number of authors and institutions. 
Table 1 - Amount and percentage of articles, authors, institutions and countries per decade.

\begin{tabular}{ccccccccc}
\hline \multirow{2}{*}{ Decade } & \multicolumn{2}{c}{ Articles } & \multicolumn{2}{c}{ Authors } & \multicolumn{2}{c}{ Institutions } & \multicolumn{2}{c}{ Countries } \\
\cline { 2 - 8 } & $\mathrm{n}$ & $\%$ & $\mathrm{n}$ & $\%$ & $\mathrm{n}$ & $\%$ & $\mathrm{n}$ & $\%$ \\
\hline 1910 & 84 & 2.44 & 13 & .53 & 3 & .50 & 2 & 4.26 \\
1920 & 118 & 3.43 & 69 & 2.83 & 16 & 2.66 & 7 & 14.89 \\
1930 & 313 & 9.11 & 152 & 6.24 & 45 & 7.48 & 13 & 27.66 \\
1940 & 283 & 8.24 & 167 & 6.86 & 48 & 7.97 & 14 & 29.79 \\
1950 & 368 & 10.7 & 257 & 10.55 & 78 & 12.96 & 28 & 59.57 \\
1960 & 436 & 12.7 & 301 & 12.36 & 106 & 17.61 & 32 & 68.09 \\
1970 & 354 & 10.3 & 227 & 9.32 & 91 & 15.12 & 28 & 59.57 \\
1980 & 408 & 11.9 & 285 & 11.70 & 76 & 12.62 & 15 & 31.91 \\
1990 & 423 & 12.3 & 405 & 16.63 & 114 & 18.94 & 13 & 27.66 \\
2000 & 397 & 11.6 & 536 & 22.00 & 158 & 26.25 & 16 & 34.04 \\
2010 & 252 & 7.33 & 503 & 20.65 & 118 & 19.60 & 16 & 34.04 \\
\hline Total & 3,436 & 100 & 2,436 & 100 & 602 & 100 & 47 & 100 \\
\hline
\end{tabular}

Note: $\mathrm{n}=$ frequency; $\%$ = in relation to total articles $(3,436)$, authors $(2,436)$, institutions $(602)$ and countries (47).

Sport Sciences documents have been disseminated in 12 journals, being Educación Física-Chile and Archivos de la Sociedad Chilena de Medicina del Deporte (Archivos SOCHMEDEP) the most important ones, with the publication of 1900 and 852 documents respectively, both gathering a $80.1 \%$ of total output (see Table 2). They are also the longest still published journals in contrast to Revista de Educación Física, Revista de Educación Física del Ejército de Chile, Heracles or Gymnasium, which were only edited in certain periods.

This output was divided in 23 subjects from four different research areas (see Table 3). Life Sciences and Biomedicine followed by Social Sciences with 1,598 and 1,366 documents respectively were the most represented ones. Three subjects led this production with more than 400 articles, such as Physical Education and Sports Theory (PE\&ST), Physiology and Sports Medicine, collecting both $51.22 \%$ of total documents. Regarding the subjects' distribution per decade, a group of nine subjects has been always represented, while Anatomy, Computer Science, Law and Sciencemetris have scarcely appeared in one decade.

Regarding the collaboration patterns, there exist an increasing number of multiauthored articles along time and firstly exceeding the amount of single-authored articles in the decade of 2010 (see Table 4). Thus, the percentage of collaboration has been constantly increasing, achieving a total mean of 1.50 authors per article. 
Table 2 - Amount and percentage of articles per journal and decade.

\begin{tabular}{|c|c|c|c|c|c|c|c|c|c|c|c|c|c|c|c|c|c|c|c|c|c|c|c|c|}
\hline \multirow{2}{*}{ Journal } & \multicolumn{2}{|c|}{ Total } & \multicolumn{2}{|c|}{1910} & \multicolumn{2}{|c|}{1920} & \multicolumn{2}{|c|}{1930} & \multicolumn{2}{|c|}{1940} & \multicolumn{2}{|c|}{1950} & \multicolumn{2}{|c|}{1960} & \multicolumn{2}{|c|}{1970} & \multicolumn{2}{|c|}{1980} & \multicolumn{2}{|c|}{1990} & \multicolumn{2}{|c|}{2000} & \multicolumn{2}{|c|}{2010} \\
\hline & $\mathrm{n}$ & $\%$ & $\mathrm{n}$ & $\%$ & $\mathrm{n}$ & $\%$ & $\mathrm{n}$ & $\%$ & $\mathrm{n}$ & $\%$ & $\mathrm{n}$ & $\%$ & $\mathrm{n}$ & $\%$ & $\mathrm{n}$ & $\%$ & $\mathrm{n}$ & $\%$ & $\mathrm{n}$ & $\%$ & $\mathrm{n}$ & $\%$ & $\mathrm{n}$ & $\%$ \\
\hline Educación Física-Chile & 1,900 & 55.30 & & & 118 & 3.43 & 313 & 9.11 & 221 & 6.43 & 303 & 8.82 & 230 & 6.69 & 172 & 5.01 & 240 & 6.98 & 191 & 5.56 & 98 & 2.85 & 14 & .41 \\
\hline Archivos SOCHMEDEP & 852 & 24.80 & & & & & & & & & 65 & 1.89 & 206 & 6 & 182 & 5.30 & 164 & 4.77 & 167 & 4.86 & 62 & 1.80 & 6 & .17 \\
\hline Motricidad humana & 120 & 3.49 & & & & & & & & & & & & & & & & & & & 57 & 1.66 & 63 & 1.83 \\
\hline $\begin{array}{l}\text { Ciencias de la Actividad Física } \\
\text { U.C.M. }\end{array}$ & 114 & 3.32 & & & & & & & & & & & & & & & & & 10 & .29 & 57 & 1.66 & 47 & 1.37 \\
\hline $\begin{array}{l}\text { Revista Ciencias de la Actividad } \\
\text { Física }\end{array}$ & 114 & 3.32 & & & & & & & & & & & & & & & & & 53 & 1.54 & 55 & 1.60 & 6 & .17 \\
\hline Revista de Educación Física & 84 & 2.44 & 84 & 2.44 & & & & & & & & & & & & & & & & & & & & \\
\hline Revista de las Ciencias de la & & & & & & & & & & & & & & & & & & & & & & & & \\
\hline $\begin{array}{l}\text { Actividad Física del Instituto } \\
\text { Nacional de Deportes }\end{array}$ & 63 & 1.83 & & & & & & & & & & & & & & & & & & & 32 & .93 & 31 & .90 \\
\hline Motricidad y Persona & 62 & 1.80 & & & & & & & & & & & & & & & & & & & 36 & 1.05 & 26 & .76 \\
\hline $\begin{array}{l}\text { Revista de Educación Física del } \\
\text { Ejército de Chile }\end{array}$ & 62 & 1.80 & & & & & & & 62 & 1.80 & & & & & & & & & & & & & & \\
\hline Horizonte & 59 & 1.72 & & & & & & & & & & & & & & & & & & & & & 59 & 1.72 \\
\hline Heracles & 4 & .12 & & & & & & & & & & & & & & & 4 & .12 & & & & & & \\
\hline Gymnasium & 2 & .06 & & & & & & & & & & & & & & & & & 2 & .06 & & & & \\
\hline
\end{tabular}

Note: $\mathrm{n}$ = frequency; $\%$ = in relation to total number of articles $(3,436)$.

Source: prepared by authors. 
Table 3 - Distribution of articles per research area, subject and decade.

\begin{tabular}{|c|c|c|c|c|c|c|c|c|c|c|c|c|c|c|c|c|c|c|c|c|c|c|c|c|}
\hline \multirow{2}{*}{ Research area \& subject } & \multicolumn{2}{|c|}{1910} & \multicolumn{2}{|c|}{1920} & \multicolumn{2}{|c|}{1930} & \multicolumn{2}{|c|}{1940} & \multicolumn{2}{|c|}{1950} & \multicolumn{2}{|c|}{1960} & \multicolumn{2}{|c|}{1970} & \multicolumn{2}{|c|}{1980} & \multicolumn{2}{|c|}{1990} & \multicolumn{2}{|c|}{2000} & \multicolumn{2}{|c|}{2010} & \multicolumn{2}{|c|}{ Total } \\
\hline & $\mathrm{n}$ & $\%$ & $\mathrm{n}$ & $\%$ & $\mathrm{n}$ & $\%$ & $\mathrm{n}$ & $\%$ & $\mathrm{n}$ & $\%$ & $\mathrm{n}$ & $\%$ & $\mathrm{n}$ & $\%$ & $\mathrm{n}$ & $\%$ & $\mathrm{n}$ & $\%$ & $\mathrm{n}$ & $\%$ & $\mathrm{n}$ & $\%$ & $\mathrm{n}$ & $\%$ \\
\hline Arts \& Humanities & 14 & ,41 & 6 & 17 & 23 & 67 & 43 & 1,25 & 41 & 1,19 & 47 & 1,37 & 19 &, 55 & 29 & 84 & 17 & ,49 & 11 &, 32 & 5 & 15 & 255 & 7,42 \\
\hline Architecture & & & 1 &, 03 & & & & & & & & & & & & & & & 1 &, 03 & & & 2 & ,06 \\
\hline History & 14 & ,41 & 4 & ,12 & 23 & 67 & 42 & 1,22 & 41 & 1,19 & 47 & 1,37 & 19 &, 55 & 29 & 84 & 16 & 47 & 10 & ,29 & 4 & ,12 & 249 & 7,25 \\
\hline Philosophy & & & 1 &, 03 & & & 1 &, 03 & & & & & & & & & 1 & ,03 & & & 1 &, 03 & 4 &, 12 \\
\hline Life Sciences \& Biomedicine & 9 & ,26 & 29 & 84 & 109 & 3,17 & 90 & 2,62 & 181 & 5,27 & 224 & 6,52 & 212 & 6,17 & 228 & 6,64 & 226 & 6,58 & 164 & 4,77 & 126 & 3,67 & 1598 & 46,51 \\
\hline Anatomy & & & & & & & 1 & ,03 & & & & & & & & & & & & & & & 1 & ,03 \\
\hline Anthropology & & & & & & & & & & & 1 &, 03 & & & & & & & 2 &, 06 & & & 3 & ,09 \\
\hline Anthropometry & & & & & 6 & 17 & 2 & ,06 & 4 & 12 & 4 & ,12 & 7 & 20 & 11 & ,32 & 25 & ,73 & 15 & ,44 & 19 &, 55 & 93 & 2,71 \\
\hline Biomechanics & 3 & 09 & 2 & ,06 & 12 &, 35 & 7 & ,20 & 12 &, 35 & 6 & ,17 & 7 & ,20 & 7 & ,20 & 16 & ,47 & 13 & ,38 & 16 & ,47 & 101 & 2,94 \\
\hline Health Care & & & & & 4 & ,12 & 1 & ,03 & 6 & ,17 & 1 & ,03 & 6 & ,17 & 8 & ,23 & 15 & ,44 & 14 &, 41 & 6 & ,17 & 61 & 1,78 \\
\hline Kinesiology & & & 1 & ,03 & & & 4 & ,12 & 6 & ,17 & 13 & ,38 & 2 &, 06 & 1 & ,03 & 6 & 17 & 2 & ,06 & 1 & ,03 & 36 & 1,05 \\
\hline Nutrition & 1 &, 03 & 2 &, 06 & 6 & ,17 & 9 & ,26 & 14 & ,41 & 8 & ,23 & 4 & ,12 & 8 & ,23 & 2 & 06 & 11 & ,32 & 6 &, 17 & 71 & 2,07 \\
\hline Physiology & 2 &, 06 & 6 & ,17 & 32 & ,93 & 38 & 1,11 & 63 & 1,83 & 77 & 2,24 & 71 & 2,07 & 91 & 2,65 & 83 & 2,42 & 51 & 1,48 & 42 & 1,22 & 556 & 16,18 \\
\hline Sports Medicine & 2 &, 06 & 11 &, 32 & 28 &, 81 & 15 & ,44 & 55 & 1,60 & 83 & 2,42 & 75 & 2,18 & 83 & 2,42 & 40 & 1,16 & 32 & 93 & 11 & ,32 & 435 & 12,66 \\
\hline Sports Training Theory & 1 & ,03 & 7 &, 20 & 21 &, 61 & 13 & ,38 & 21 & ,61 & 31 & 90 & 40 & 1,16 & 19 &, 55 & 39 & 1,14 & 24 &, 70 & 25 & ,73 & 241 & 7,01 \\
\hline Social Sciences & 33 & ,96 & 77 & 2,24 & 160 & 4,66 & 116 & 3,38 & 121 & 3,52 & 131 & 3,81 & 118 & 3,43 & 146 & 4,25 & 160 & 4,66 & 188 & 5,47 & 116 & 3,38 & 1366 & 39,76 \\
\hline Didactics & 12 &, 35 & 6 & ,17 & 27 &, 79 & 23 & ,67 & 20 &, 58 & 8 & ,23 & 16 & ,47 & 11 & ,32 & 23 & ,67 & 32 & 93 & 13 & ,38 & 191 & 5,56 \\
\hline Law & & & & & & & & & & & & & & & & & & & 1 & ,03 & & & 1 & ,03 \\
\hline PE\&ST & 20 &, 58 & 66 & 1,92 & 123 & 3,58 & 78 & 2,27 & 79 & 2,30 & 77 & 2,24 & 60 & 1,75 & 94 & 2,74 & 77 & 2,24 & 69 & 2,01 & 26 & ,76 & 769 & 22,38 \\
\hline Psychology & 1 & ,03 & 3 &, 09 & 5 & ,15 & 11 &, 32 & 5 &, 15 & 28 &, 81 & 34 & 99 & 21 &, 61 & 20 &, 58 & 27 &, 79 & 37 & 1,08 & 192 & 5,59 \\
\hline Psychomotor education & & & & & & & & & 3 & ,09 & 2 &, 06 & 3 &, 09 & 8 & ,23 & 28 & 81 & 28 &, 81 & 22 & 64 & 94 & 2,74 \\
\hline Sociology & & & 2 & ,06 & 5 & 15 & 4 & 12 & 14 & ,41 & 16 & 47 & 5 & ,15 & 12 & ,35 & 12 & ,35 & 31 & ,90 & 18 &, 52 & 119 & 3,46 \\
\hline Technology & 28 &, 81 & 6 & 17 & 21 & ,61 & 34 & 99 & 25 & ,73 & 34 & ,99 & 5 & ,15 & 5 & ,15 & 20 & ,58 & 34 & 99 & 5 & 15 & 217 & 6,32 \\
\hline Computer Science & & & & & & & & & & & & & & & 1 & ,03 & & & & & & & 1 & ,03 \\
\hline Documentation & & & & & 2 & ,06 & 3 & ,09 & 3 & ,09 & & & 1 & ,03 & 1 & ,03 & 4 & 12 & 7 & ,20 & 2 & ,06 & 23 & 67 \\
\hline Management & 28 &, 81 & 6 & 17 & 19 &, 55 & 31 & ,90 & 22 & 64 & 34 & 99 & 4 & ,12 & 3 & ,09 & 16 & 47 & 27 & ,79 & 2 & ,06 & 192 & 5,59 \\
\hline Sciencemetrics & & & & & & & & & & & & & & & & & & & & & 1 & ,03 & 1 & ,03 \\
\hline
\end{tabular}

(J) Movimento, Porto Alegre, v. 22, n. 4, 1121-1136, out./dez. de 2016. 
Table 4 - Distribution of the amount of single-authored articles, multi-authored articles, mean of authors per article, and percentage of collaboration per decade.

\begin{tabular}{ccccc}
\hline Decade & $\begin{array}{c}\text { Single-authored } \\
\text { articles }\end{array}$ & $\begin{array}{c}\text { Multi-authored } \\
\text { articles }\end{array}$ & Mean authors/ article & \% of collaboration \\
\hline $\mathbf{1 9 1 0}$ & 84 & & 1 & \\
1920 & 118 & 12 & 1 & \\
1930 & 301 & 41 & 1.08 & 3.83 \\
1940 & 242 & 33 & 1.30 & 14.49 \\
1950 & 335 & 56 & 1.13 & 8.97 \\
1960 & 380 & 54 & 1.21 & 12.84 \\
1970 & 300 & 126 & 1.31 & 15.25 \\
1980 & 282 & 162 & 1.74 & 30.88 \\
1990 & 261 & 158 & 1.82 & 38.30 \\
2000 & 239 & 1.95 & 39.80 \\
2010 & 61 & 191 & 2.96 & 75.79 \\
\hline Total & 2603 & 833 & 1.54 & 24.24 \\
\hline \multicolumn{5}{r}{}
\end{tabular}

\section{DISCUSSION}

Sport Sciences scientific production published in Chile began in 1912 with the publication of the Revista de Educación Física. Until 2014, 12 journals have contributed to the dissemination of their 3,436 documents, participating 2,436 authors from 602 different institutions pertaining to 47 countries. PE\&ST, Physiology and Sports Medicine have been the most represented subjects along time. Single-authored articles have dominated Sport Sciences in Chile, despite in the last decade the percentage of collaboration has achieved $75.79 \%$.

Sport Sciences in Chile, and particularly Physical Education, was officialized and become an university's degree in 1906 with the establishment of the Physical Education and Manual Institute under the patronage of the University of Chile (COFRÉ ILUFFI, 1986, COFRÉ ILUFFI, 1989, GUARDA ETCHEVERRY, 2006), reflecting the increasing social and political interest about physical activities and gymnastics from the $19^{\text {th }}$ century onwards (GUARDA ETCHEVERRY, 2006, RUIZ URBINA, 1956). The appearance of a scientific journal also represented the academic interest for developing this field of knowledge (PÉREZ-GUTIÉRREZ; GUTIÉRREZ-GARCÍA, 2015).

Nevertheless, until 2014 Sport Sciences scientific production has been interrupted in three periods due to different reasons. The first break occurred from 1916 to 1928 . The first specialized journal in Chile, Revista de Educación Física, was a particular initiative and after four years of publication disappeared in 1916 (PÉREZ-GUTIÉRREZ; LAGOS-HERNÁNDEZ, 2015). In 1929, a new initiative was supported by the Physical Education and Manual Institute, starting its own publication titled Educación Física-Chile, which has been considered the oldest one in the world in its topic (GUARDA ETCHEVERRY, 2006, SALAS, 1989), although it has been edited under four different titles (PÉREZ-GUTIÉRREZ; GUTIÉRREZ-GARCÍA, 2015). 
Secondly, Sport Sciences production was interrupted in 1932 and 1933. The serious economic crisis happened in Chile as a consequence of the Great Depression's worldwide effects (COLLIER; SATER, 1996) together with the political instability of that period (COLLIER; SATER, 1996, SILVA GALDAMES, 1995) have been argued as the main reasons for the disappearance of the only journal published in that period, Educación Física-Chile (PÉREZGUTIÉRREZ; GUTIÉRREZ-GARCÍA, 2015).

The third interruption occurred in 1973, probably due to the social and political tension that finally led to a coup d'état and the establishment of Pinochet's military regime (COLLIER; SATER, 1996, SILVA GALDAMES, 1995). Universities and public institutions were military controlled and several academics as well as students and administrative staff were removed due to this fact (GARRETÓN; MARTíNEZ, 1985, HUNEEUS, 1988).

The distribution of results per decade shows a clearer perspective of Sport Sciences scientific production published in Chile. Thus, the number of articles has irregularly increased until the 1960s and then achieved a steady-state around 400 publications during the following decades. Exception is found in the 1970s probably due to the already mentioned coup d'état happened in 1973. Because half of the current decade has passed and 252 articles have been already published, it seems the scientific output will overcome the values of previous decades. Authors and institutions contributing to this production, and their distribution shown in Table 1, are corroborating this rise of Sport Sciences field in Chile during the last decades. Moreover, eight out of the 12 Sport Sciences journals have been published in Chile from the 1990s onwards (Table 2), which represents a broadening of this field and a higher interest of academics and editors for developing and disseminating research in this area (PÉREZ-GUTIÉRREZ; LAGOSHERNÁNDEZ, 2015). Andrade et al., (2013) also corroborated this growth, finding South American research in Sport Sciences published in ISI Web of Knowledge increased significantly from 1998 onwards, being Brazil, Argentina and Chile the most productive countries. However, the amount of countries participating presents a different evolution along time in contrast to articles, authors or institutions. It increased until the 1960s when achieved its maximum with 32 different countries collaborating, followed by a decrease until the 1990s and a steady-state of 16 countries represented during the last two decades (Table 1).

The increasing number of articles, authors, institutions and countries involved in research until the 1960s reflected the creation, development and spreading of a new research area like Sport Sciences, but this growth was not followed by the amount of journals since only four were published, two of them for a brief life span (Table 2). Later on, Sport Sciences began to adjust itself and establish its final structure, adapting the amount of journals to the increasing scientific production, authors and institutions. After the explosion of countries participating in Sport Sciences until the 1960s, the appearance of foreign countries decreased significantly until the end of the century. During the $21^{\text {st }}$ century, the amount of countries collaborating has been maintained but there have existed a progress within Sport Sciences depicted in the increasing collaboration among authors (Table 4).

In relation to journals, 12 periodicals have disseminated Sport Sciences research in Chile from 1912 to 2014, although some of them for a short life span. That is the case of Revista de 
Educación Física, Revista de Educación Física del Ejército de Chile, Heracles or Gymnasium, which only appeared for a few years (PÉREZ-GUTIÉRREZ; LAGOS-HERNÁNDEZ, 2015). On the other hand, Educación Física-Chile and Archivos SOCHMEDEP have been edited during 85 years (PÉREZ-GUTIÉRREZ; GUTIÉRREZ-GARCÍA, 2015), and 58 years respectively (PÉREZGUTIÉRREZ; LAGOS-HERNÁNDEZ, 2015, SOCHMEDEP, 2015), both of them collecting $80.1 \%$ of total production and becoming the main vehicles for the spreading of Sport Sciences output. However, they show an important decrease in the number of published articles during the last two decades that could be explained by the appearance of a group of six journals from the 1990s onwards, increasing the competence for publishing research documents. Probably, these periodicals have progressively appeared due to the interest of academics and institutions for spreading their own studies (PÉREZ-GUTIÉRREZ; LAGOS-HERNÁNDEZ, 2015) but also the need for having more means for publishing the increasing research developed in Sport Sciences and carrying the communication among scholars (DEVÍS-DEVÍS et al., 2011). Moreover, Villamón et al., (2007) found similar results with $65 \%$ of total Sport Sciences journals published in Spain appearing from 1991 onwards.

Regarding research areas, documents have been mainly focused on Life and Social Sciences, collecting $46.51 \%$ and $39.76 \%$ of total production respectively. Despite their relevance, they present a quite different pattern of publication. Social Sciences have been constantly increasing the number of published articles, while Life Sciences have grown until the 1990s.

However, the development of research interest among academics has changed along the studied period. Social Sciences collected the greatest amount of articles until the 1940s in comparison with other areas, but from the 1950s to the end of the century Life Sciences have headed Sport Sciences scientific output in Chile. This change in research interest should be related to the different approaches surrounding Sport Sciences in general, which is explained in the following subject's analysis. During the $21^{\text {st }}$ century, a new scenario has appeared presenting both Social and Life Sciences a similar production. This situation should be understood as a consolidation of this field of study and its academics' involvement in research. The enactment of 19712 Law of Sport in 2001 stated the relevance of physical activity and sport for the Chilean society and created the National Institute of Sports as well as the National Fund for Sports Promotion (MINISTERIO DEL INTERIOR, 2001). This law was focused on the promotion of sport and physical activities to general population but especially to children, elders or disabled people, and the funds were allocated to the development of programmes, activities and projects related to the promotion of Sport Sciences (MINISTERIO DEL INTERIOR, 2001: artículo 43a). Therefore, these facts could triggered research in all areas of knowledge, groups of people or physical activities consequently. Nevertheless, future studies should analyze research areas involved in Chilean Sport Sciences articles published in databases such as Web of Science or Scopus since they could present a deeper viewpoint of these areas' output.

Finally, 23 different subjects were represented, confirming its multi-disciplinary character (DEVÍS DEVÍS et al., 2010, VALENCIANO VALCÁRCEL; DEVÍS DEVÍS; BELTRÁN CARRILLO, 2008, VICENTE PEDRAZ, 1998). A group of three subjects has collected more than $50 \%$ of total production, such as Physiology, Sports Medicine and PE\&ST. However, the reasons explaining the relevance of these subjects are quite different. The interest of Chilean academics 
in Physiology and Sports Medicine was reflected on the biological approach leading the teaching of physical education professionals from the 1930s onwards in the Physical Education Institute at the University of Chile, which gave rise to most of Sport Sciences' institutions in Chile (COFRÉ ILUFFI, 1989). In this Institute, physiology, biology, biochemistry and nutrition labs were created, kinesiology degree was included within the syllabus and medical professionals were hired for teaching (BISQUERTT SUSARTE, 1957, COFRÉ ILUFFI, 1989, GUARDA ETCHEVERRY, 2006). Sports Medicine was also triggered by the establishment of the Chilean Society of Sports Medicine in 1955 and the subsequent events organized such as congresses, scientific meetings, workshops and courses (SOCHMEDEP, 2015). Moreover, several studies have corroborated the relevance of Sports Medicine and Physiology within Sport Sciences. These subjects were the main topics represented in South American Sport Sciences production published in the Web of Knowledge (ANDRADE et al., 2013) and were included among the five most represented subjects after analyzing 16 Sport Sciences journals published in Spain from 1999 to 2005 (DEVÍS DEVÍS et al., 2010). In addition, Physiology was the second subject collecting more number of articles published within National Institute of Sports' journal (PÉREZGUTIÉRREZ; LAGOS-HERNÁNDEZ, 2015).

On the other hand, PE\&ST is a core subject focused on the clarification of concepts, approaches and paradigms related to Sport Sciences, delimiting this field of knowledge. Thus, the increasing number of institutions offering Sport Sciences degrees on their syllabus, from 12 organizations in 1989 to more than 30 at present time (CANEF, 2015, MINEDUC, 2015) has risen the amount of academics and their interest for researching, spreading, developing and updating the knowledge and boundaries in their field of study. The constant amount of articles about PE\&ST as well as the appearance of new subjects such as Architecture, Philosophy, Anthropology, Law or Sciencemetrics during the last decades should be understood because of the good condition and strength of Sport Sciences in Chile, reflecting its process of consolidation.

\section{CONCLUSIONS}

The Chilean scientific production about Sport Sciences began in 1912 with the appearance of the first specialized journal, six years after the establishment of the Physical Education and Manual Institute. Both social, political and academic interests during that period propelled the beginning and development of this field of knowledge. Up to now, this output has been disseminated in 12 periodicals, two of them collecting $80.1 \%$ of total documents, and it has been interrupted in three periods due to different social, political, economic and cultural events. Firstly, the disappearance of the first sports-oriented journal caused the break from 1916 to 1928. Secondly, the worldwide effects of the Great Depression together with the political instability of the country stopped the Sport Sciences research dissemination from 1932 to 1933 . Thirdly, the coup d'état carried out in 1973 by Pinochet's regime caused the interruption of journals' publication during 1973.

In summary, Sport Sciences scientific production could be divided in three different phases. The first phase happened from the beginning of the $20^{\text {th }}$ century to the 1950 s and was characterized by the progressive rise of articles, authors, institutions and countries. The 
research was focused on Social Sciences and collaboration among academics was low. The second phase lasted from the 1960 s to the end of the $20^{\text {th }}$ century and was characterized by the strengthening of Sport Sciences research, reflected on the rise of articles, journals, authors and institutions involved as well as the percentage of collaboration among academics. However, the number of countries collaborating decreased, and research focus was turned to Life Sciences. Finally, during the third phase, from the beginning of the $21^{\text {st }}$ century to the present day, Sport Sciences has started a process of consolidation through the stabilization of the number of articles published, the group of specialized journals edited, the research areas and subjects studied and the strengthening of collaboration patterns among academics.

Future studies should analyze Chilean scientific production about Sport Sciences published at the international level and indexed in databases such as Web of Science or Scopus for complementing the present results and assessing the amount of articles reaching the top scientific journals.

\section{REFERENCES}

ABARZÚA ALARCÓN, Esteban. Chilenos de oro. Santiago: Don Bosco, 2005.

ANDRADE, David Cristobal et al. Bibliometric analysis of South American research in sports science from 1970 to 2012. Motriz, v. 19, n. 4, p. 783-791, 2013.

ARAVENA, Pedro; CARTES-VELASQUEZ, Ricardo; MANTEROLA, Carlos. Productividad y calidad metodológica de artículos clínicos en cirugía oral y maxilofacial en Chile. Período 2001-2012. Revista Chilena de Cirugía, v. 65, n. 5, p. 382-388, 2013.

BISQUERTT SUSARTE, Luis. El Instituto de Educación Física y Técnica en su medio siglo. Revista Chilena de Educación Física, v. 22, n. 91-92, p. 3-26, 1957.

CARTES-VELÁSQUEZ, Ricardo; ARAVENA TORRES, Pedro. Perfil bibliométrico de la odontología chilena, 2001-2010. Revista clínica de periodoncia, implantología y rehabilitación oral, v. 5, n. 1, p. 5-8, 2012.

CASALI FUENTES, Aldo. Reforma universitaria en Chile, 1967-1973. Pre-balance histórico de una experiencia frustrada. Intus-Legere Historia, v. 5, n. 1, p. 81-101, 2011.

COFRÉ ILUFFI, Milton. El DEFDER y sus 80 años: el Instituto Superior de Educación Física y Técnica, hoy Departamento de Educación Física, Deportes y Recreación. Educación Física-Chile, v. 57, n. 208, p. 12-15, 1986.

COFRÉ ILUFFI, Milton. El Instituto de Educación Física y Manual: ocho décadas. Educación FísicaChile, v.61, n. 219, p. 9-19, 1989.

COLLIER, Simon; SATER, William F. A History of Chile, 1808-1994. Cambridge: Cambridge University Press, 1996.

CORNEJO AMÉSTICA, Miguel; MATUS CASTILLO, Carlos; VARGAS CONTRERAS, Camilo. La Educación Física en Chile: una aproximación histórica. Lecturas: Educación fisica y deportes, v. 16, n. 161, 2011. Disponible en: < http://www.efdeportes.com/efd161/la-educacion-fisica-en-chile.htm>. Acceso en: 5 mayo 2015. 
DEVÍS-DEVÍS, José et al. Las revistas españolas de Ciencias de la Actividad Física y el Deporte: características, calidad y elementos de mejora. DDxt-e, Revista Andaluza de Documentación sobre el Deporte, n. 1, p. 1-12, 2011.

DEVÍS DEVÍS, José et al. Disciplinas y temas de estudio en las ciencias de la actividad física y el deporte. Revista Internacional de Medicina y Ciencias de la Actividad Física y del Deporte,v. 10, n. 37, p. 150-166, 2010.

FERREIRA BARROS CARNEIRO, Felipe et al. Uma revista em movimento: contribuiçoes para a subárea sociocultural e pedagógica da Educação Física brasileira (2004-2014). Movimento, v. 22, n. 1, p. 11-34, 2016.

FLORENZANO, Ramón et al. Un análisis bibliométrico de los trabajos libres de psiquiatría presentados a congresos de la Sociedad Chilena de Neurología, Psiquiatría y Neurocirugía entre 2000 y 2009. Revista Chilena de Neuro-Psiquiatría, v. 49, n. 2, p. 200-205, 2011.

GÁLVEZ, Marcelo et al. Realidad de la Revista Chilena de Radiología 2010-2014. Revista Chilena de Radiología, v. 21, n. 1, p. 26-33, 2015.

GARRETÓN, Manuel Antonio; MARTÍNEZ, Javier. Universidades chilenas: historia, reforma e intervención. Santiago: SUR, 1985.

GAU, Li-Shiue. Trends and topics in sports research in the Social Science Citation Index from 1993 to 2008. Perceptual \& Motor Skills, v. 116, n. 1, p. 305-314, 2013.

GUARDA ETCHEVERRY, Sergio. Historia del Instituto de Educación Física. Educación física Chile, n. 265, p. 13-24, 2006.

HUNEEUS, Carlos. La reforma universitaria: veinte años después. Santiago: Corporación de Promoción Universitaria, 1988.

JAKSIC, Fabián M.; SANTELICES, Bernabe. ¿Alguien lee a los ecólogos chilenos? Revista Chilena De Historia Natural, v. 64, n. 1, p. 13-18, 1991.

KRAUSKOPF, Erwin. Plant Science research productivity in Chile during the past 20 years. Biological Research, v. 41, n. 2, p. 137-141, 2008.

KRAUSKOPF, Manuel; KRAUSKOPF, Erwin. Una mirada epistemométrica de la Revista Médica de Chile y su aporte al conocimiento en Medicina. Revista Medica de Chile, v. 136, n. 8, p. 1065-1072, 2008.

LAGOS-HERNÁNDEZ, Roberto Iván; PÉREZ-GUTIÉRREZ, Mikel. Análisis bibliométrico de las tesis de pregrado: el caso de Pedagogía en Educación Física de la Universidad Autónoma de Chile (20072012). Revista Iberoamericana de Educación, v. 70, n. 1, p. 181-200, 2016.

LÓPEZ LÓPEZ, Pedro. Introducción a la bibliometría. Valencia: Promolibro, 1996

MARÍN, Edgardo. Historia del deporte chileno: entre la ilusión y la pasión. Santiago: Comisión Bicentenario, 2007

MARTÍNEZ-FERNÁNDEZ, Felipe. Hacia una pedagogía del cuerpo. La Educación Física en Chile, 1889-1920. Ágora para la educación física y el deporte, v. 14, n. 3, p. 320-331, 2012.

MODIANO, Pilar. Historia del deporte chileno: orígenes y transformaciones, 1850-1950. Santiago: DIGEDER, 1997.

MORAGA, Javier et al. Publicaciones de autores chilenos en revistas quirúrgicas durante los últimos diez años. Revista Chilena de Cirugía,v. 64, n. 5, p. 447-451, 2012. 
MORENO-DOÑA, Alberto; GAMBOA JIMÉNEZ, Rodrigo. Dictadura Chilena y Sistema Escolar: "a otros dieron de verdad esa cosa llamada educación”. Educar em Revista, n. 51, p. 51-66, 2014.

MORENO DOÑA, Alberto; GAMBOA JIMÉNEZ, Rodrigo; POBLETE GÁLVEZ, Carolina Alejandra. La Educación Física en Chile: análisis crítico de la documentación ministerial. Revista Brasileira de Ciências do Esporte, v. 36, n. 2, p. 411-427, 2014.

MOYA-ANEGÓN, Félix de. Principales indicadores cienciométricos de la actividad científica chilena 2012. Informe 2014: una mirada a 10 años. Madrid : Valparaíso: Altazor Ediciones, 2014.

MUÑOZ FUNCK, Cristian. Historia de la Dirección General de Deportes y Recreación: las políticas estatales de fomento al deporte. DIGEDER 1948-2001. Santiago: Instituto Nacional de Deportes, 2001.

MUÑOZ FUNCK, Cristian. Chilenos Olímpicos. Historia de la Participación Nacional en los Juegos Olímpicos de Verano. 1896-2008. Santiago: Comité Olímpico de Chile, 2008.

PÉREZ-GUTIÉRREZ, Mikel; GUTIÉRREZ-GARCÍA, Carlos. Estudio bibliométrico sobre las monografías de artes marciales publicadas en España (1906-2006). Revista de Artes Marciales Asiáticas, v. 3, n. 4, p. 22-33, 2008.

PÉREZ-GUTIÉRREZ, Mikel; GUTIÉRREZ-GARCÍA, Carlos. Historia de la revista Educación FísicaChile: aproximación bibliométrica (1929-2013). Movimento, v. 21, n. 3, p. 603-616, 2015.

PÉREZ-GUTIÉRREZ, Mikel; LAGOS-HERNÁNDEZ, Roberto Iván. Análisis bibliométrico de los artículos publicados en la revista del Instituto Nacional de Deportes: 2004-2014. Revista de las Ciencias de la Actividad Física del Instituto Nacional de Deportes, n. 10, p. 7-18, 2015.

PÉREZ-GUTIÉRREZ, Mikel; LAGOS-HERNÁNDEZ, Roberto Iván. Sport Sciences scientific journals in Chile (1929-2014): bibliography, characteristics, quality. Motriz, v. 21, n. 4, p. 442-451, 2015.

PERRINO PEÑA, María. Análisis bibliométrico, temático e ideológico de la revista de estudios deportivos Citius, Altius, Fortius (1959-1976). León: Universidad de León, 2014.

POBLETE GÁLVEZ, Carolina Alejandra; MORENO DOÑA, Alberto; RIVERA GARCÍA, Enrique. Educación Física en Chile: Una historia de la disciplina en los escritos de la primera publicación oficial del Instituto de Educación Física de la Universidad de Chile (1934-1962). Estudios Pedagógicos, Valdivia, v. 40, n. 2, p. 265-282, 2014.

RAU, Jaime R. Indice-h de Universidades chilenas líderes en investigación y su relación con rankings basados en la percepción de su prestigio. Información, cultura y sociedad, n. 18, p. 77-84, 2008.

RUIZ URBINA, Antonio. Bosquejo histórico del Instituto de Educación Física y Técnica de la Universidad de Chile. Revista Chilena de Educación Física, v. 22, n. 90, p. 1523-1599, 1956.

SALAS, Rosauro. 60 años de una revista: Educación Física, Chile. Educación Física-Chile, v. 60, n. 218, p. 4-8, 1989.

SILVA GALDAMES, Osvaldo. Breve historia contemporánea de Chile. México D.F.: Fondo de Cultura Económica, 1995.

SOLÍS VALENZUELA, Hernán. Historia de los Juegos Olimpicos: chilenos medallistas en cinco juegos olímpicos. Santiago: [s.n.], 2003.

VALENCIANO VALCÁRCEL, Javier; DEVÍS DEVÍS, José; BELTRÁN CARRILLO, Vicente Javier. La investigación y las revistas científicas de la actividad física y el deporte en España. Fuentes: Revista de la Facultad de Ciencias de la Educación, n. 8, p. 209-218, 2008. 
VALENCIANO VALCÁRCEL, Javier et al. La colaboración científica en el campo de las Ciencias de la Actividad Física y el Deporte en España. Revista española de documentación científica, v. 33, n. 1, p. 90-105, 2010.

VILLAMÓN, Miguel et al. Características y difusión de las revistas científico-técnicas españolas de ciencias de la actividad física y el deporte. El profesional de la información, v. 16, n. 6, p. 605-616, 2007. 
Apoio:

Comisión Nacional de Investigación Científica y Tecnológica (CONICYT). 